\title{
Prevalence of Type-2 Diabetes in Patients with Hepatitis C and B Virus Infection in J eddah, Saudi Arabia
}

\author{
Daad H. Akbar Aisha M. Siddique Maimona M. Ahmed \\ Department of Medicine, King Abdulaziz University Hospital, J eddah, Saudi Arabia
}

\section{Key Words}

Type-2 diabetes · Hepatitis C · Hepatitis B · Saudi Arabia

\begin{abstract}
Objectives: To determine the prevalence of type-2 diabetes mellitus (DM) in patients with hepatitis $C$ virus $(\mathrm{HCV})$ and $B$ virus (HBV) infections. Materials and Methods: A cross-sectional study of HCV- and HBV-positive patients admitted to King Abdul Aziz University Hospital, J eddah, Saudi Arabia, was conducted from J anuary 1999 to September 2000. The following data were collected and analysed: demographic data, the presence and type of DM, details of the treatment, body mass index (BMI), family history of DM, serum transaminases, thrombocytopenia, and presence of liver cirrhosis on liver biopsy. A total of 399 patients were included in the study. Results: 165 (41\%) were anti-HCV positive and 234 (59\%) were HBsAg positive. Type-2 diabetes was present in 35 of 165 (21.2\%) patients with HCV infection, and 33 of 234 (14.1\%) with HBV infection. 94\% of anti-HCV-positive type-2 diabetes were older than 40 years and $6 \%$ were younger, while for nondiabetics the corresponding percentages were 55 and $45 \%$, respectively. $76 \%$ of HBsAg-positive type-2 diabetics were older than 40 and $24 \%$ were younger, while the corresponding percent-
\end{abstract}

ages for nondiabetics were 27 and $73 \%$, respectively. Anti-HCV-positive type-2 diabetics, when compared to nondiabetics, had a higher BMI, a frequent family history of DM, elevated serum transaminases, thrombocytopenia, and liver cirrhosis on biopsy. HBsAg-positive type-2 diabetics had only a more frequent family history of DM than did nondiabetics. Conclusion: Our findings indicate that type-2 diabetes is more common in patients with an $\mathrm{HCV}$ than with an HBV infection.

Copyright (C2002 S. Karger AG, Basel

\section{Introduction}

Diabetes mellitus (DM) and chronic hepatitis $\mathrm{C}$ virus (HCV) and B virus (HBV) infections are relatively common disorders. In Saudi Arabia prevalences of 7.4, 2.3, and $5.2 \%$ have been reported for DM, HCV and HBV infections, respectively [1-3]. A higher prevalence of type$2 \mathrm{DM}$ has been observed in patients infected with $\mathrm{HCV}$ than in those infected with HBV [4-9]. However, the prevalence of type-2 DM in HCV and HBV infections has not been reported in Saudi Arabia. The aim of this study, therefore, was to determine the prevalence of type-2 DM in patients with $\mathrm{HCV}$ and $\mathrm{HBV}$ infections.

\begin{tabular}{ll}
\hline KARGER & @ 2002 S. Karger AG, Basel \\
1011-7571/02/0112-0082\$18.50/0 \\
$\begin{array}{l}\text { Fax +4161306 12 34 } \\
\text { Ewail karger@karger.ch } \\
\text { wwarger.com }\end{array}$ & $\begin{array}{l}\text { Accessible online at: } \\
\text { www.karger.com/journals/mpp }\end{array}$
\end{tabular}

Dr. Daad Hassan Akbar, Associate Professor/Consultant Physician

PO Box 18298

Jeddah 21415 (Kingdom of Saudi Arabia)

Tel. +966 255604 854, E-Mail daadakb@yahoo.com 


\section{Materials and Methods}

A cross-sectional study of $\mathrm{HCV}$ - and HBV-positive patients admitted to King Abdul Aziz University Hospital, Jeddah, Saudi Arabia, was conducted during the period of January 1999 to September 2000. Laboratory records of 413 patients for whom HCV and HBV serology was done were reviewed. Fourteen were excluded, as the presence of DM could neither be confirmed by anamnesis nor by the presence of hyperglycemia; the remaining 399 patients were included in the study. The presence of anti-HCV and HBs antigens was assessed using the microparticle enzyme immunoassay. Medical records were reviewed and the following data were collected: patient's age, sex, nationality, body mass index (BMI) measured in $\mathrm{kg} / \mathrm{m}^{2}$; the presence of DM was diagnosed either by a history of DM, or a fasting blood glucose $>7 \mathrm{mmol} / \mathrm{l}$, or a random blood glucose $>11.1 \mathrm{mmol} / \mathrm{l}$ ), type ( 1 or 2 ) and treatment (diet only, oral hypoglycemic agents, insulin, or combined). In addition to a family history of $\mathrm{DM}$, elevated serum transaminases ( $>3$-fold), thrombocytopenia $\left(<100 \times 10^{9}\right.$ cells/l), and presence of liver cirrhosis on liver biopsy were recorded.

\section{Statistical Analysis}

A general descriptive analysis was performed to compare type-2 DM patients with HCV and HBV infections to nondiabetics. The $\chi^{2}$ test was used for categorical variables, and the Student $t$ test for continuous variables. All statistical analyses were performed using SPSS, and a $\mathrm{p}$ value $<0.05$ was considered significant.

\section{Results}

One hundred and sixty-five patients (41\%) were antiHCV positive, 234 (59\%) HBsAg positive, and 32 (19\%) of the 399 were both anti-HCV and HBsAg positive. In the HCV-positive patient group (table 1), 2 (1.5\%) had type-1 DM, while 35 (21.2) had type-2 DM. The mean age of the type- $2 \mathrm{DM}$ patients was $53.6 \pm 14.4$ years, while that of nondiabetics was $40.2 \pm 16.5$; the difference was statistically significant $(\mathrm{p}<0.001)$. Most of the type- 2 diabetics, 19 of $35(54 \%)$, were using oral hypoglycemic agents, while $10(29 \%)$ were on insulin, $5(14 \%)$ on diet only and $1(3 \%)$ on combined treatment. Liver biopsy was done in 43 patients (11 diabetics and 32 nondiabetics); 8 of the $11(73 \%)$ diabetics and 20 of the $32(62 \%)$ nondiabetics had mild steatosis, respectively. The prevalence of type-2 DM was greatest in patients who were non-Saudis, older than 40 years, had a high BMI and a frequent family history of DM. Compared to the nondiabetics, they were also more likely to have raised serum transaminases, low platelets, and histological evidence of cirrhosis.

In the HBsAg-positive patient group (table 2), 8 of 234 (3\%) had type-1 and 33 (14.1\%) had type-2 DM. The mean age of type- 2 diabetics was $49.7 \pm 13$ years, while that for nondiabetics was $33.3 \pm 14.6$ years and the dif-

Type-2 Diabetes in Patients with

Hepatitis C and B Virus Infection
Table 1. Comparison between diabetic and nondiabetic patients with $\mathrm{HCV}$ infection

\begin{tabular}{lrrc}
\hline Variable & $\begin{array}{l}\text { Type-2 } \\
\text { diabetics } \\
\mathrm{n}=35\end{array}$ & $\begin{array}{l}\text { Non- } \\
\text { diabetics } \\
\mathrm{n}=128\end{array}$ & p value \\
\hline $\begin{array}{lrrr}\text { Age } \\
>40 \text { years }\end{array}$ & $33(94)$ & $70(55)$ & $<0.001$ \\
$<40$ years & $2(6)$ & $58(45)$ & \\
\hline Sex & & & \\
Males & $21(60)$ & $79(62)$ & 0.85 \\
Females & $14(40)$ & $49(38)$ & \\
\hline BMI & & & \\
$>25 \%$ & $20(57)$ & $55(43)$ & 0.05 \\
$<25 \%$ & $15(43)$ & $73(57)$ & \\
\hline Nationality & & & \\
Saudis & $13(37)$ & $54(42)$ & 0.07 \\
Non-Saudis & $22(63)$ & $74(58)$ & \\
Family history of diabetes & $15(43)$ & $21(16)$ & $<0.001$ \\
Raised serum transaminases & $25(71)$ & $72(56)$ & 0.03 \\
Low platelets count & $10(29)$ & $29(23)$ & 0.05 \\
Cirrhosis on liver biopsy ${ }^{1}$ & $3(27)$ & $4(13)$ & 0.03 \\
\hline
\end{tabular}

Figures in parentheses are percentages.

1 Liver biopsy was done in 11 diabetics and 32 nondiabetics.

Table 2. Comparison between diabetic and nondiabetic patients with HBV infection

\begin{tabular}{lrrr}
\hline Variable & $\begin{array}{l}\text { Type-2 } \\
\text { diabetics } \\
\mathrm{n}=33\end{array}$ & $\begin{array}{l}\text { Non- } \\
\text { diabetics } \\
\mathrm{n}=193\end{array}$ & $\mathrm{p}$ value \\
\hline Age & $25(76)$ & $52(27)$ & $<0.001$ \\
$>40$ years & $8(24)$ & $141(73)$ & \\
$<40$ years & & & \\
Sex & $17(52)$ & $79(41)$ & 0.26 \\
Males & $16(48)$ & $114(59)$ & \\
Females & & & \\
\hline BMI & $22(67)$ & $117(61)$ & 0.57 \\
$>25 \%$ & $11(33)$ & $76(39)$ & \\
$<25 \%$ & & & \\
\hline Nationality & $21(64)$ & $117(61)$ & 0.85 \\
Saudis & $12(36)$ & $76(39)$ & \\
Non-Saudis & $15(45)$ & $48(25)$ & 0.02 \\
Family history of diabetes & $10(30)$ & $48(25)$ & 0.02 \\
Raised serum transaminases & $5(15)$ & $14(7)$ & 0.16 \\
Low platelets count & $1(33)$ & $5(33)$ & 1.0 \\
Cirrhosis on liver biopsy ${ }^{1}$ & &
\end{tabular}

Figures in parentheses are percentages.

1 Liver biopsy was done in 3 diabetics and 15 nondiabetics. 
ference was statistically significant $(\mathrm{p}<0.001)$. Most of the diabetics, 21 of $33(64 \%)$, were using oral hypoglycemic agents, while $6(18 \%)$ were on diet only, $5(15 \%)$ on insulin, and $1(3 \%)$ on combined treatment. Liver biopsy was done in 18 patients ( 3 diabetics and 15 nondiabetics); mild steatosis was found in 1 of the $3(33 \%)$ diabetics and 4 of the $15(27 \%)$ nondiabetics. The prevalence of type- 2 DM was greatest in older patients and in those who had a frequent family history of DM.

\section{Discussion}

In addition to liver involvement, $\mathrm{HCV}$ infections can cause extrahepatic diseases such as essential mixed cryoglobulinemia, sporadic porphyria cutanea tarda, and thyroid disorders, probably due to an interaction between HCV and the host immune system [10-13]. Mehta et al. [14] and Allison et al. [15] have reported that patients infected with HCV are 3-5 times more likely to have type2 DM than those without HCV. Type-2 DM and insulin resistance syndrome have been hypothesized to constitute manifestations of an ongoing acute-phase response [16, 17]. This hypothesis is based on the findings of increased blood concentration in the acute-phase response markers, including C-reactive protein, serum amyloid-A, $\alpha_{1}$-acid glycoprotein, sialic acid cortisol [16-19], and interleukin-6, a cytokine involved in the regulation of acute-phase reaction and immune response [20]. Thus HCV might stimulate an immunological reaction that leads to a high prevalence of type-2 DM. Reports from different parts of the world have shown an increased prevalence of type-2 DM amongst patients with chronic HCV infection (24$62 \%$ ) compared to persons with other forms of liver diseases [4, 21, 22]. Our study showed a prevalence of $21 \%$, which is consistent with previous reports. A lower prevalence of type-2 DM was found in patients with $\mathrm{HBV}$ infection (14\%), a finding that is also in agreement with previous reports of $8-12 \%[4,6,8,9,14]$. An HCV infection may take 15 years or more to cause cirrhosis [23, 24]. Thus HCV infection might cause diabetes by another mechanism, e.g. as a result of progressive liver damage. This is supported by the observation that an increased prevalence of DM occurs mainly among $\mathrm{HCV}$-infected patients with liver cirrhosis $[6,15,25]$. Caronia et al. [6] have reported that patients with cirrhosis had insulin resistance in addition to decreased acute insulin responsiveness. Mehta et al. [14] also found an association between the development of DM and a low platelet count, an early indication of hepatic dysfunction. Our study showed that patients infected with HCV who developed type-2 DM were more likely to have a low platelet count, elevated transaminases and histological evidence of liver cirrhosis (table 1). On the other hand, no relation was found between $\mathrm{HBV}$-infected patients who developed type-2 DM and chronic liver dysfunction (table 2).

BMI, age, ethnic origin, and a family history of DM also appear to be associated with type-2 DM patients infected with $\mathrm{HCV}$ (table 1). A high BMI, age and a strong family history of DM have been reported in type-2 DM patients infected with HCV [14], consistent with our findings. In agreement with our study, an association with ethnic origins has not been reported; whether ethnic origin plays a role in the development of DM needs further studies. Only age and a frequent family history of DM appear to be associated with type-2 DM patients infected with HBV (table 2). El-Zayadi et al. [7] had reported an increased prevalence of type-2 DM in the infected persons using insulin while in our study most of the patients were using oral hypoglycemic agents for blood glucose control.

\section{Conclusion}

Our findings indicate that type- 2 diabetes was more common in patients with HCV than in those with HBV infections. Moreover, type-2 DM in the presence of an $\mathrm{HCV}$ infection appears to be associated with more clinical indications than type-2 DM in the presence of an HBV infection. Further studies are needed on this field which will be reflected by possible treatment or prevention of DM by antiviral agents or vaccination. 


\section{References}

1 Al-Hasmi MA, Alswailem A, Wasry AS, Sulimani R: Prevalence of diabetes mellitus in Saudi Arabia. Saudi Med J 1995;16:294-299.

2 Fathala S, al-Jama A, Badawy M, Sabry H, Awad O, Abdulaziz F, Elnajar M: Prevalence of hepatitis-C virus infection in the eastern province of Saudi Arabia by Re-DNA second generation and supplemental ELA tests. Saudi Med J 1994;15:281-285.

3 Takieddine F, Tufenkeji H, Sheth K, Ghandour M: Prevalence of HBV marker in adult Saudis in relation to age and sex. Ann Saudi Med 1986;6:205-210.

4 Mason AL, Lau JY, Hoang N, Qian KP, Alexander GJ, Xu L, Guo L, Jacob S, Regenstein FG, Zimmerman R, Everhart JE, Wasserfall C, Maclaren NK, Perrillo RP: Association of diabetes mellitus and chronic hepatitis $\mathrm{C}$ virus infection. Hepatology 1999;29:328-333.

5 Grimbert S, Valensi P, Levy-Marchal C, Perret G, Richardet JP, Raffoux C, Trinchet JC, Beaugrand M: High prevalence of diabetes mellitus in patients with chronic hepatitis C. A case-control study. Gastroenterol Clin Biol 1996;20:544-548.

6 Caronia S, Taylor K, Pagliaro L, Carr C, Palazzo U, Petrik J, O'Rahilly S, Shore S, Tom BD, Alexander GJ: Further evidence of an association between non-insulin-dependent diabetes mellitus and chronic hepatitis $\mathrm{C}$ virus infection. Hepatology 1999;30:1059-1063.

7 El-Zayadi AR, Selim OE, Hamdy H, Dabbous $\mathrm{H}$, Ahdy $\mathrm{H}$, Moniem SA: Association of chronic hepatitis $\mathrm{C}$ infection and diabetes mellitus. Trop Gastroenterol 1998;19:141-144.

8 Knobler H, Schihmanter R, Zifroni A, Fenakel $\mathrm{G}$, Schattner A: Increased risk of type-s diabetes mellitus in noncirrhotic patients with chronic hepatitis $\mathrm{C}$ virus infection. Mayo Clin Proc 2000;75:355-359.
9 Zein NN, Abdulkarim AS, Wiesner RH, Egan KS, Persing DH: Prevalence of diabetes mellitus in patients with end-stage liver cirrhosis due to hepatitis $\mathrm{C}$, alcohol, or cholestatic disease. J Hepatol 2000;32:209-217.

10 Agnello V, Chung RT, Kaplan LM: A role for hepatitis $\mathrm{C}$ virus infection in type II cryoglobulinemia. N Engl J Med 1992;327:1490-1495.

11 Bonkovsky HL, Poh-Fitzpatrick M, Pimstone N, Obando J, Di Bisceglie A, Tattrie C, Tortorelli K, LeClair P, Mercurio MG, Lambercht RW: Porphyria cutanea tarda, hepatitis C, and HFE gene mutations in North America. Hepatology 1998;27:1661-1669.

12 Strassburg CP, Obermayer-Straub P, Manns MP: Autoimmunity in hepatitis $\mathrm{C}$ and $\mathrm{D}$ virus infection. J Viral Hepat 1996;3:49-59.

13 Tran A, Quaranta JF, Benzaken S, Thiers V, Chau HT, Hastier P, Regnier D, Dreyfus G, Partier C, Sadoul JL, et al: High prevalence of thyroid autoantibodies in a prospective series of patients with chronic hepatitis $\mathrm{C}$ before interferone therapy. Hepatology 1993;18:253257.

14 Mehta SH, Brancati FL, Sulkowski MS, Strathdee SA, Szklo M, Thomas DL: Prevalence of type-2 diabetes mellitus among persons with hepatitis $\mathrm{C}$ virus infection in the United States. Ann Intern Med 2000;133:592-599.

15 Allison ME, Wreghitt T, Palmer CR, Alexander GJ: Evidence for a link between hepatitis C virus infection and diabetes mellitus in a cirrhotic population. J Hepatol 1994;21:11351139.

16 Pickup JC, Mattock MB, Chusney GD, Burt D: NIDDM as a disease of the innate immune system: Association of acute phase reactant and interleukin-6 with metabolic syndrome X. Diabetologia 1997;40:1286-1292.
17 Pickup JC, Crook MA: Is type II diabetes mellitus a disease of the innate immune system? Diabetologia 1998;41:1241-1248.

18 Jonsson A, Wales JK: Blood glycoprotein level in diabetes mellitus. Diabetologia 1976;12: 245-250.

19 McMillan DE: Increased level of acute-phase serum protein in diabetes. Metabolism 1989 38:1042-1046.

20 Fernandez-Real JM, Broch M, Vendrell J, Gutierrez C, Casmaitijana R, Pugeat M, Richart $\mathrm{C}$, Ricart W: Interleukin-6 gene polymorphism and insulin sensitivity. Diabetes 2000;49:517520.

21 Knobler H, Stagnaro-Green A, Wallenstein S, Schwartz M, Roman SH: Higher incidence of diabetes in liver transplant recipients with hepatitis C. J Clin Gastroenterol 1998;26:30-33.

22 Ozyilkan E, Arslan M: Increased prevalence of diabetes mellitus in patients with chronic hepatitis $\mathrm{C}$ virus infection. Am $\mathrm{J}$ Gastroenterol 1996;91:1480-1481.

23 Alter MJ, Kruszon-Moran D, Nainan OV McQuillan GM, Gao F, Moyer LA, Kaslow RA, Margolis HS: The prevalence of hepatitis C virus infection in the United States, 1988 through 1994. N Engl J Med 1999;341:556562.

24 Tong MJ, el-Farra NS, Reikes AR, Co RL: Clinical outcomes after transfusion associated hepatitis C. N Engl J Med 1995;332:14631466.

25 Mangia A, Schiavone G, Lezzi G, Marmo R, Bruno F, Villani MR, Cascavilla L, Fantasia L, Andriulli A: HCV and diabetes mellitus: Evidence for a negative association. Am J Gastroenterol 1998;93:2363-2367. 